\title{
Couple Communication as a Mediator Between Work-Family Conflict and Marital Satisfaction
}

\author{
Sarah J. Carroll \\ Brigham Young University - Provo
}

Follow this and additional works at: https://scholarsarchive.byu.edu/etd

Part of the Family, Life Course, and Society Commons

\section{BYU ScholarsArchive Citation}

Carroll, Sarah J., "Couple Communication as a Mediator Between Work-Family Conflict and Marital Satisfaction" (2012). Theses and Dissertations. 3347.

https://scholarsarchive.byu.edu/etd/3347

This Thesis is brought to you for free and open access by BYU ScholarsArchive. It has been accepted for inclusion in Theses and Dissertations by an authorized administrator of BYU ScholarsArchive. For more information, please contact scholarsarchive@byu.edu, ellen_amatangelo@byu.edu. 


\title{
Couple Communication as a Mediator Between Work-Family Conflict and Marital Satisfaction
}

\author{
Sarah June Carroll
}

A thesis submitted to the faculty of

Brigham Young University

in partial fulfillment of the requirements for the degree of

Master of Science

E. Jeffrey Hill, Chair

Jeffry H. Larson

Jonathan G. Sandberg

Jeremy B. Yorgason

School of Family Life

Brigham Young University

August 2012

Copyright (C) 2012 Sarah June Carroll

All Rights Reserved 


\section{ABSTRACT \\ Couple Communication as a Mediator Between \\ Work-Family Conflict and Marital Satisfaction \\ Sarah June Carroll \\ School of Family Life, BYU \\ Master of Science}

Using a sample of married individuals employed full-time $(N=1,139)$, this study examined the mediating effects of constructive and destructive communication between partners on the relationship between work-family conflict and marital satisfaction. Results from structural equation modeling revealed that work-family conflict was significantly and negatively related to marital satisfaction. This relationship became insignificant when constructive and destructive communication were added to the model, evidence for full mediation. This was confirmed with Sobel's test for mediation. Results suggest that teaching communcation skills may be a potent point of intervention for couples who experience high levels of work-family conflict.

Keywords: work-family conflict, marital satisfaction, couples, communication 


\section{Table of Contents}

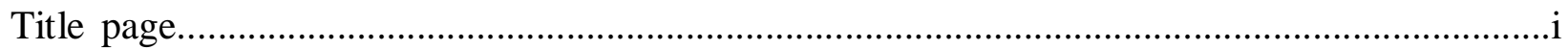

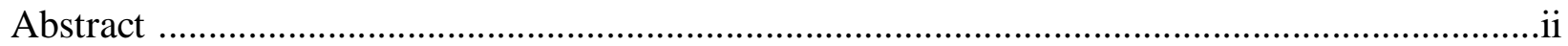

Table of Contents ..............................................................................................................ii

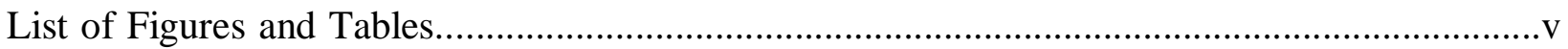

Couple Communication as a Mediator Between Work-Family Conflict and Marital Satisfaction.1

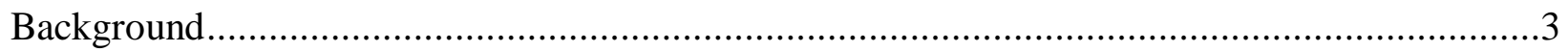

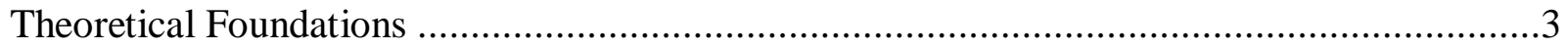

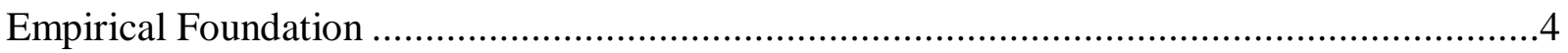

Work-family conflict and marital satisfaction.......................................................4

Constructive communication and marital satisfaction ............................................5

Destructive couple communication and marital satisfaction ......................................6

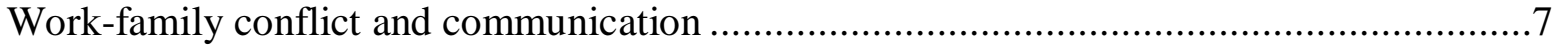

Communication as a mediator ............................................................................8

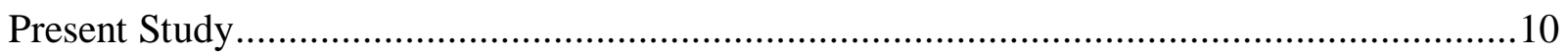

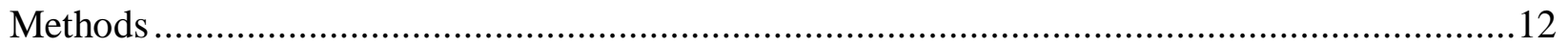

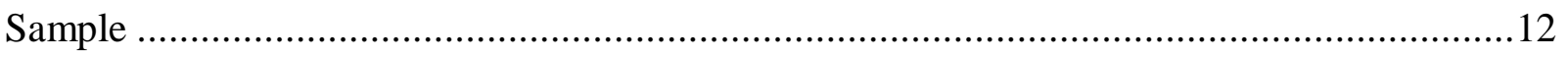

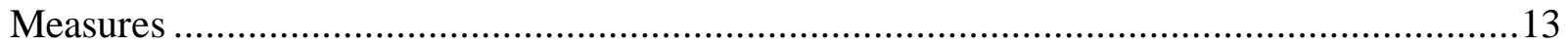

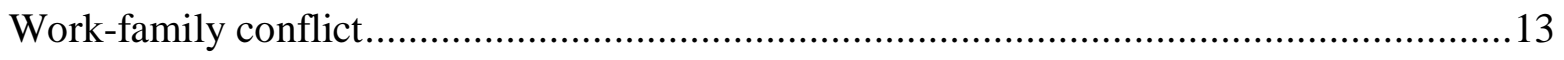

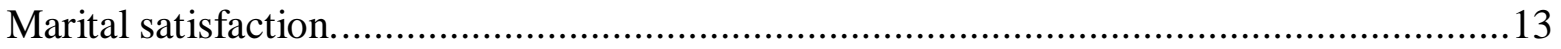

Constructive communication......................................................................... 16

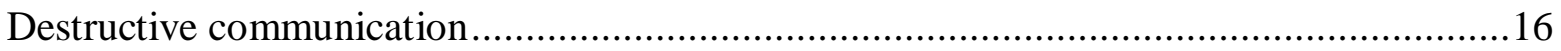

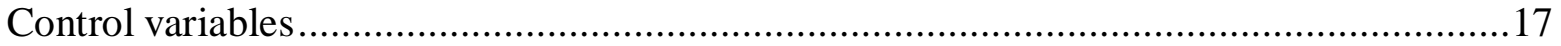




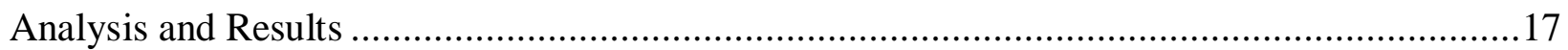

Work-Family Conflict and Marital Satisfaction............................................................19

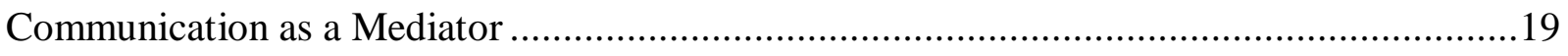

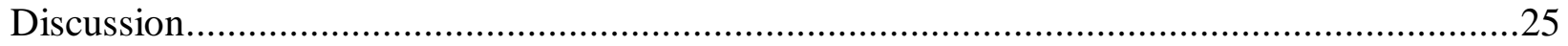

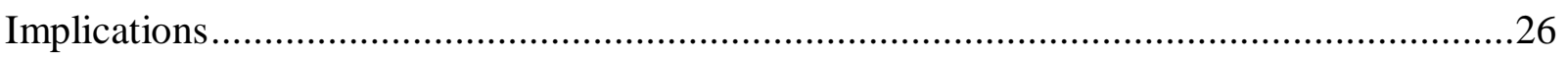

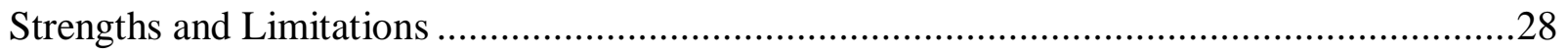

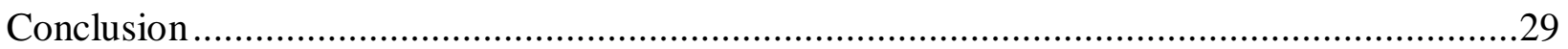

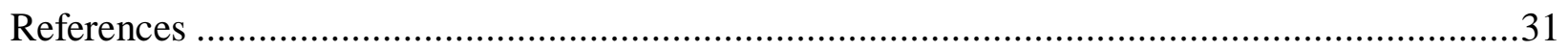


List of Figures and Tables

Figure 1. Conceptual Model....................................................11

Figure 2. Hypothesis One Results.........................................20

Figure 3. Baron and Kenny Hypothesis..........................................21

Figure 4. Hypotheses Two and Three Results...................................22

Table 1. Factor Loadings......................................................14

Table 2. Means, Standard Deviation and Correlations.................................18

Table 3. Decomposition of Standardized Effects..................................24 


\section{Couple Communication as a Mediator Between Work-Family Conflict and Marital}

\section{Satisfaction}

The stress of managing the conflicting demands between paid work and family life can negatively influence couple marital satisfaction (see Allen, Herst, Bruck, \& Sutton, 2000; Ford, Heinen \& Langkamer, 2007; Michel, Mitchelson, Kotrba, LeBreton, \& Baltes, 2009; Hill, Fellows, Chiu, \& Hawkins, 2011). In a dual-earner world, this strain can be exacerbated and the conflict between family life and work can acutely affect one’s marriage. Couples married five years or less identified balancing job and family as the most problematic issue, even above frequency of sexual relations and financial stresses (Risch, Riley, \& Lawler, 2003). Because work-family conflict is an issue that affects many couples, it merits scholarly attention.

Work-family conflict, the difficulty in managing the demands of work and family life, affects families directly. Allen et al. (2000) conducted a meta-analytic review of the outcomes of work-family conflict (WFC). They found that greater levels of WFC were associated with lower life satisfaction, lower marital adjustment, and lower family satisfaction (see also Michel et al., 2009). Furthermore, Day and Chamberlain (2006) found a negative correlation between WFC and commitment to one's spouse; the greater the conflict, the less commitment.

Work-family conflict is also associated with negative outcomes in the workplace. Conflict between work and home is associated with lower job satisfaction, fewer promotions, less effort given to work, less loyalty to the organization, and greater intentions to leave a company (Allen et al., 2000; Hill, 2005; Kossek \& Ozeki, 1998; Voydanoff, 2005).

Marital satisfaction itself is associated with many positive outcomes for individuals, families, and society as a whole. Those reporting greater satisfaction in their marriage are more likely to report stability in that marriage (Bui, Peplau, \& Hill, 1996). Marriage appears to be 
beneficial for individuals; married people report living a healthier lifestyle, having better mental health, experiencing greater sexual satisfaction, being better off financially and being better parents (see Waite \& Gallagher, 2000). Therefore, satisfaction in a stable relationship is beneficial for individuals on many levels.

On the other hand, the negative outcomes of low marital satisfaction can be problematic. Hawkins and Booth (2005) found that a long-term, low-quality marriage has significant negative effects on overall well being, including lower overall happiness, poorer life satisfaction, less selfesteem, poorer overall health and increased psychological distress. Gottman's (1994) research demonstrated that a decline in marital satisfaction may lead to consideration of separation/divorce, which often leads to separation and may lead to divorce. A large amount of literature has emerged in recent decades that has documented the negative outcomes of divorce, especially to children (see Wallerstein, Lewis \& Blakeslee, 2000). Marital satisfaction, therefore, is a key variable to understanding what factors can maintain marital satisfaction, or buffer the effects of stressors that may lead to dissatisfaction.

Couple communication is one variable that has been consistently linked to marital satisfaction. Couple communication patterns are qualitatively different for distressed and nondistressed couples (Gottman, 1994), implying that how a couple interacts is a key indicator of the quality and stability of their relationship. Furthermore, the quality of couple communication has been found to be one of the best predictors of relationship satisfaction (Holman, 2001). Therefore, in an examination of marital satisfaction, couple communication is a relevant variable to examine in connection with work-family conflict.

A negative relationship exists between work-family conflict and marital satisfaction. Multiple meta-analyses and reviews of literature have documented this relationship (see Allen et 
al., 2000; Ford et al., 2007; Michel et al., 2009; Hill et al., 2011). These reviews of the literature indicate that work-family conflict does indeed negatively impact the satisfaction of a marriage. However, the process of this relationship is not yet completely understood. Particularly, there is a paucity of research about what factors might mediate this relationship. Two recent meta-analyses did not examine mediators (Allen et al., 2000; Ford et al., 2007). Hill et al., (2011) found in their meta-analyses of work-family conflict and couple relationship quality that there were large amounts of variability in the correlations, implying existence of mediators that may be examined to more fully understand this relationship.

The purpose of this study is to begin to fill this gap in the literature by examining the mediating effects of negative and positive couple communication on the relationship between work-family conflict and marital satisfaction. If the quality of couple communication mediates the relationship of work-family conflict to marital satisfaction, then improving the quality of couple communication might be a potent point of intervention for couples experiencing workfamily conflict. This information could be useful both to marriage and family therapists, relationship educators, employers and individuals.

\section{Background}

\section{Theoretical Foundations}

Family stress theory provides a theoretical foundation to the present model (Hill, 1958). Difficulty in managing the demands of work and family life is a normative stressor. For some couples, it leads to crises, or marital distress. For others, the stress does not necessarily lead to a crisis. The Double ABCX crisis theory (McCubbin \& Patterson, 1983) offers a possible explanation for what makes the difference in whether the stressor of work-family conflict will lead to crises in marital relationships. The theory suggests that the level of crisis depends on not 
only the stressor event or hardship, but that resources and the perception of the stress are key factors as well. Multiple stressors pile up over time necessitating coping and leading to adaptation (McCubbin \& Patterson, 1983). This model has been applied to work-family conflict in previous studies (Dennis, 1996; Hill, 2005).

Constructive communication is a resource or a capability that a couple can use to cope with the demands of managing work and family life. It also may affect the subjective meaning of work-family conflict. The stress of work demands, if accompanied with the resources and the coping abilities of constructive communication, may prevent distress in the relationship.

However, if destructive communication accompanies discussion of work-family conflict, the perception of how work affects family life would be more distressing than if the destructive communication were not present. Therefore, quality of communication as a resource may be a possible mediator of the relationship between work-family conflict and marital satisfaction.

\section{Empirical Foundation}

Work-family conflict and marital satisfaction. Greenhaus and Beutell (1985) in their landmark study of the work-family interface define work-family conflict as "a form of interrole conflict in which the role pressures from the work and family domains are mutually incompatible in some respect. That is, participation in the work (family) role is made more difficult by virtue of participation in the family (work) role” (p. 77). Risk factors or predictors of work-family conflict include workplace strain, work hours, and an inflexible work environment (Byron, 2005).

Studies have consistently reported a negative relationship between work-family conflict and marital satisfaction. Allen et al. (2000) in a review of 67 articles found a negative correlation between work-family conflict and marital satisfaction. In a meta-analysis of 120 studies, Ford et al., (2007) also found a negative correlation between work-family conflict and family satisfaction 
(which included marital satisfaction). In a model that compiled the findings of 211 studies, work-family conflict was negatively correlated with family satisfaction, a construct that included marital satisfaction (Michel et al., 2009). Another meta analysis of 72 studies (Hill et al., 2011) reported a moderately strong negative correlation between work-family conflict and couple relationship quality.

In addition to numerous studies in the United States, this relationship between workfamily conflict and marital satisfaction has been found in Taiwan (Wu, Chang \& Zhuang, 2010), Scotland (Swanson \& Power, 1999) and the Netherlands (Bakker, Demerouti, \& Burke, 2009). Job satisfaction, which is correlated with work-family conflict, also has an effect on marital satisfaction over time (Ilies, Wilson \& Wagner, 2009). Workaholism, which is closely related with work-family conflict, influences not only the employee’s perception of relationship satisfaction, but the partner's perception of relationship satisfaction, as well. This is an indirect crossover effect mediated by work-family conflict and support provided to the partner (Bakker et al., 2009). These studies establish empirical support for the assertion that work-family conflict has a negative relationship with marital satisfaction.

Constructive communication and marital satisfaction. Constructive communication is an accurate predictor of relationship quality (Holman, 2001; Johnson et al., 2005; Pasch \& Bradbury, 1998; Larson \& Holman, 1994). Lewis and Spanier (1979) in a review of literature found that communication skills (self disclosure, accuracy of nonverbal communication, frequency of successful communication, understanding between spouses and empathy) were positively related to a relationship quality. Feeney (1994) found that mutually constructive communication is strongly correlated with marital satisfaction. In a sample of individuals in dual-earner marriages, marital quality was predicted by couple communication (Perrone \& Worthington, 2001). 
Furthermore, relationship maintenance behaviors lead not only to that individual's relationship satisfaction, but their partner’s satisfaction as well (Weigel \& Ballard-Reisch, 2008).

Constructive communication also involves support from a spouse. The perception of sufficient support from a spouse is correlated with and accounts for unique variance in marital quality (Dehle, Larsen, \& Landers, 2001). The impact of spousal support on marital satisfaction is stronger for women than it is for men (Acitelli \& Antounucci, 1994).

Even before a marriage begins, a couple’s interactions are likely to influence later marital quality. In a meta-analysis of 43 studies premarital predictors of marital distress (Jackson, 2009), the quality of the couple interaction before marriage was one of the most significant factors related to marital distress. Specifically, the greatest protective factor against marital distress was premarital relationship quality (e.g., love, satisfaction, support). Larson, Anderson, Holman and Niemann (1998) found that open communication before marriage was the best predictor of sexual satisfaction one year into the marriage. Interestingly, husband's empathic communication predicted the sexual satisfaction of the wife at one year into marriage, and sexual satisfaction in the first year predicts later marital satisfaction (see Henderson-King \& Veroff, 1994). Clearly the empirical research indicates that martial satisfaction is influenced by positive couple communication.

Destructive couple communication and marital satisfaction. Research suggests that destructive couple communication is associated with lower marital satisfaction (see Siffert \& Schwarz, 2011). Gottman (1994) found that destructive communication (criticism, defensiveness, contempt and stonewalling) were all found to be significantly and negatively correlated with marital quality and set a couple on a course toward divorce (Gottman \& Levenson, 1992). Withdrawal specifically predicts divorce, but only for husbands (Birditt, 
Brown, Orbuch, \& McIlvane, 2010). The relevance of destructive communication is even seen early in committed relationships. In a meta-analysis of 43 studies of premarital predictors of marital distress (Jackson, 2009), the greatest risk factor was negative premarital interactions (e.g., conflict, criticism, demand-withdraw). This shows how pervasive destructive communication may be to a relationship, even before marriage.

Johnson et al.(2005) followed the marital satisfaction of newlyweds for four years, and concluded that low levels of constructive communication coupled with high levels of destructive communication predicted deterioriation of the marriage. However, high levels of positive affect could buffer the effects of a high level of negative communication on marital satisfaction. Gottman (1994) found that in stable marriages the ratio was, on average, approximately five positive interactions for every one negative interaction. In unstable marriages, however, the positivity ratio was less than one positive interaction for every negative interaction. This empirical evidence suggests a relationship between constructive communication and destructive communication.

Work-family conflict and communication. Research suggests that both constructive and destructive couple communication may influence how work-family conflict is experienced. Work-family conflict is negatively related to providing support to one's spouse (Minnotte et al., 2007) and is associated with more blame and negative emotional displays when communicating about work issues (Green, Schaefer, MacDermid \& Weiss, 2011). The effect of destructive communication also is recursive in that it can affect the work domain as well. Negative marital interactions affect health and depression, which in turn affect the work satisfaction of both husbands and wives (Sandberg, Yorgason, Miller, \& Hill, 2012). The negative impact on work satisfaction may influence the perception of work-family conflict. This perception may in turn 
negatively influence marital interactions, thus perpetuating a cycle of negative influence. Schulz, Cowan, Cowan and Brennan (2004) found that negatively arousing workdays were linked with angrier marital behavior for women. For men, negatively arousing workdays were linked to more withdrawal behaviors. Dual earner couples report more positive marital interactions (more warmth, less conflict and less withdrawal) on days when they work less (Doumas, Margolin, \& John, 2003). It appears from these studies that couple communication may be a factor that interacts with the perception of work-family conflict, and conversely work-family conflict may interact with the quality of a couple’s communication.

Communication as a mediator. Research provides evidence for possible mediators of the negative relationship between work-family conflict and marital satisfaction. Ilies et al. (2009) found that the spillover of job satisfaction to marital satisfaction was mediated by how integrated the roles of work and family were for an employee. Work-family fit mediated the relationship between several variables in the work-family interface and marital satisfaction (Jones et al., 2008). In Finnish dual earner couples, job exhaustion and psychosomatic health mediated the spillover of job stressors (job insecurity, pressures at work, leadership relations and work-family conflict) to marital satisfaction (Kinnunen \& Mauno, 1999). Psychological distress and depression have also been noted as a mediators (Matthews, Conger \& Wickrama, 1996; Barling \& Macewen, 1992). Judge, Ilies, and Scott (2006) found the emotions of guilt and hostility mediated the relationship between work-family conflict and marital satisfaction. Hostility in this study was defined as the experience of an emotion rather than a particular form of communication between partners. Jacob, Allen, Hill, Mead and Ferris (2008), found that dinner time as a family mediated the negative influence of long work hours on marital satisfaction. Crossover effects have also been examined as explanations of work-family conflict affecting 
marital satisfaction (Matthews, Del Priore, Acitelli \& Barnes-Farrell, 2006; Bakker et al., 2009). Few, however have examined couple communication as a possible mediator between workfamily conflict and marital satisfaction.

Couple communication could be a pathway for this relationship. For example, if a husband works long hours and travels frequently this will naturally put a strain on his relationship with his wife. Furthermore, if every discussion with his wife regarding an upcoming project or business trip is wrought with criticism, defensiveness and withdrawal from the relationship, the destructive communication is the mechanism that exacerbates the impact of his work-family conflict on his satisfaction with his marriage. Conversely, if a mother is faced with a rigid and demanding work schedule as she attempts to juggle parent-teacher conferences and soccer games, this naturally could be a stressor to her relationship with her husband. Yet if their conversations about the mayhem of the day are filled with understanding and clear sending of messages, then their communication pattern may be the pathway that ameliorates the effects of the work-family conflict and provide a buffer to protect her marital satisfaction.

Little research has examined couple communication as a mediator of the relationship between work-family conflict and marital satisfaction. In a review of 190 studies from 1980 to 2002 regarding work and family, couple communication was not found to be a mediator in any of the studies examined (Eby, Casper, Lockwood, Bordeaux, \& Brinely, 2005). A few studies, however, have tested mediators that are similar to couple communication. In a sample of 337 couples from a longitudinal study, greater marital hostility mediated the relationship between work-family conflict and marital quality. Less marital warmth and supportiveness was also a mediator (Matthews et al., 1996). These effects however, were not direct but indirect pathways 
through psychological distress of the husband and wife, which in turn predicted marital interaction and thereby affected marital quality.

Spousal support is one aspect of constructive communication, and has been found to be a moderator between variables similar to work-family conflict and marital satisfaction. Support from spouse was found to buffer the effects of workload on a relationship (Repetti, 1989). Brock and Lawrence, (2008) examined spousal support as a moderator for the effect of stress spillover on marital satisfaction. They found that spousal support did buffer the effects of role strain on marital satisfaction but only for women, not for men. Work-family conflict and support provided to the partner mediated the impact of workaholism on the partner's marital satisfaction (Bakker et al., 2009). Among employed mothers, social support moderated the relationship between interrole conflict and marital satisfaction, (Macewen \& Barling, 1988) and a similar sample specifically found support from the spouse to the be moderator (Suchet \& Barling, 1986).

\section{Present Study}

Based on the family stress theory (Hill, 1958; McCubbin \& Patterson, 1983) and considerable empirical research, this study explores a theoretical model of the relationships among work-family conflict, marital satisfaction, constructive and destructive communication (See Figure 1). This model proposes the following pathways:

H1: Work-family conflict will be negatively associated with marital satisfaction.

H2: Destructive communication will mediate the negative relationship between workfamily conflict and marital satisfaction.

H3: Constructive communication will mediate the negative relationship between workfamily conflict and marital satisfaction. 
Figure 1. Conceptual Model

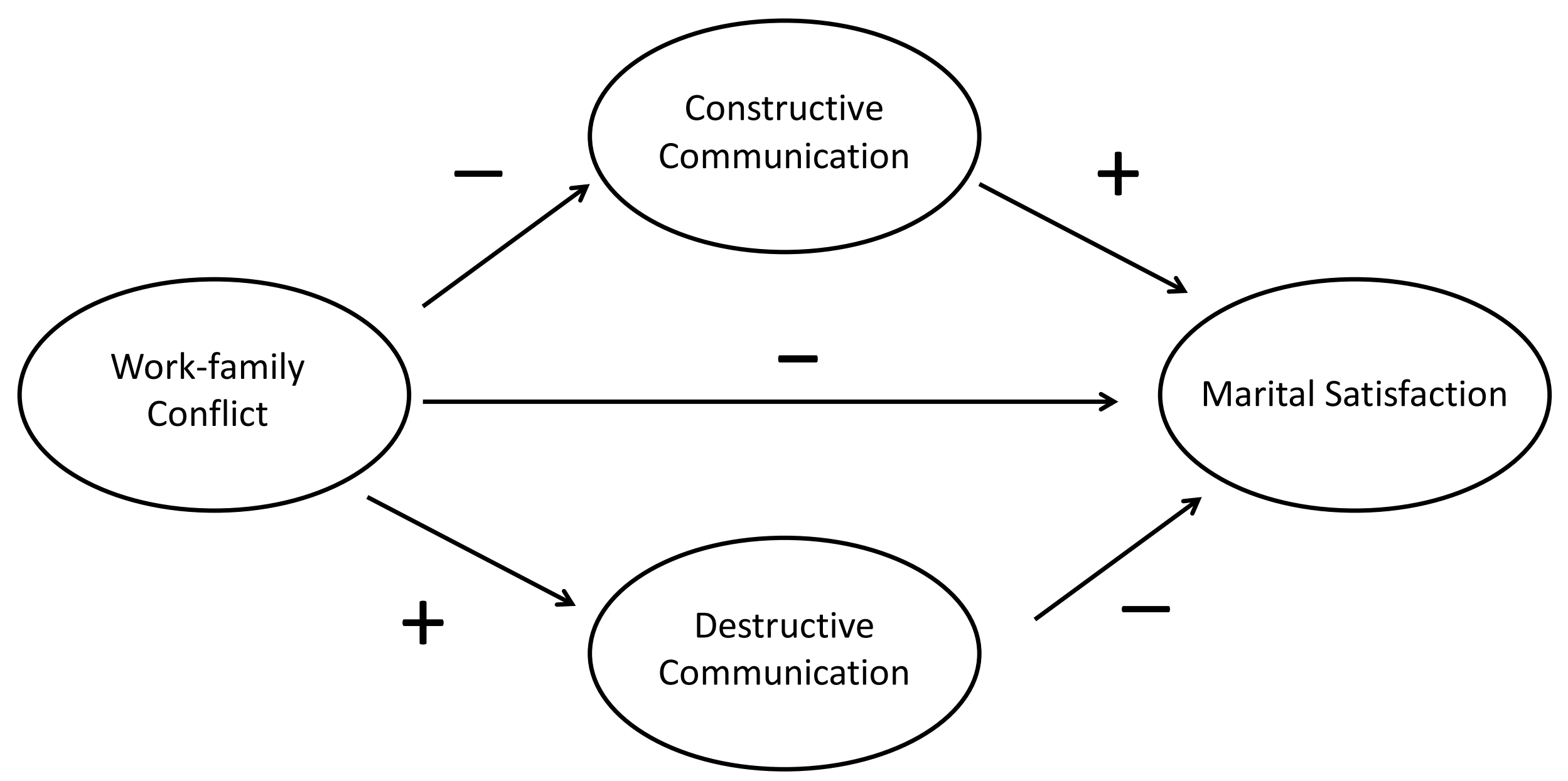




\section{Methods}

\section{Sample}

Data come from respondents to the Relationship Evaluation (RELATE), a 300-item questionnaire intended to evaluate a couple’s relationship (Holman, Busby, Doxey, Klein, \& Loyer-Carlson, 1997). Before completing the RELATE instrument, all participants completed the appropriate consent form making all data collection procedures in accordance with the university institutional review board. Participants were exposed to RELATE in a variety of ways: some were encouraged to take RELATE as a part of an undergraduate class, some from a workshop and others simply found the instrument on the internet. All participants completed RELATE online, individually.

RELATE is continuously available, however this study only included respondents that took RELATE between September 2009 and November 2011,because the variable of workfamily conflict was included in that time period. Only those individuals that were employed fulltime (35 hours a week or more) were a part of the sample for this study. Also, because the marital satisfaction scale is a variable in the study, this sample also included only those that are married. The final sample included 1,139 married individuals employed full time.

The age of the sample ranged from 19 to 72 years old, a mean 36.7 years old, with a standard deviation of 10.3 years. There were 623 men in the sample (55\%) and 516 women (45\%). Most participants were in the early to middle stages of their marriage, with 36\% married 2 years or less, $34 \% 3$ to 10 years, and 31\% married 11 or more years. The sample was highly educated with $4 \%$ receiving high school or less, $29 \%$ some college or associates degree, $23 \%$ bachelor’s degree, 44\% did some graduate work or a graduate degree. For personal yearly income 30\% earned \$0 to \$39,999, 22\% earned \$40,000-\$59,999, 25\% \$60,000-\$99,999 and 24\% 
earned \$100,000 or more per year. Hours worked per week ranged from 35 to 150 with a mean of 45.5, standard deviation of 9.3. Participants declared their ethnicity as $80 \%$ Caucasian, $6 \%$ Black, 4\% Latino, 4\% Asian, 3\% mixed/biracial, and 3\% other. Religious affiliation was self declared as 29\% Latter-day Saint (LDS), 23\% Protestant, 14\% Catholic, 4\% Jewish, 11\% other, and $20 \%$ declared no religion.

\section{Measures}

All variables are a part of the RELATE instrument. In their introductory article regarding RELATE, Busby, Holman and Taniguchi (2001) established the reliability of RELATE in three separate samples: a representative sample, a test-retest sample and an Hispanic sample. Construct validity was established for RELATE, because correlations between scales were between .45 and .65, suggesting a strong relationship between constructs, yet distinct scales. Concurrent validity was established for RELATE by comparing scales with the Revised Dyadic Adjustment Scale (RDAS). See Busby et al. (2001) for more detail.

Work-family conflict. Work-family conflict was a latent variable composed of three items on a five-point Likert scale such as: "How easy or difficult is it for you to manage the demands of your work and family life?” (See Jacob et al., 2008). Factor loadings were all above 0.759. See Table 1 for a detailed outline of factor loadings for each construct.

Marital satisfaction. Marital satisfaction was a latent variable measured by seven items answering the question: "In your relationship, how satisfied are you with the following?” Items included "The love you experience”, "How conflicts are resolved”, or "Your overall relationship with your partner”. Factor loadings were all above 0.563 . 
Table 1. Factor Loadings.

\begin{tabular}{|l|l|}
\hline Work-Family Conflict & $\begin{array}{l}\text { Factor } \\
\text { Loading }\end{array}$ \\
\hline $\begin{array}{l}\text { WFC: How easy or difficult is it for you to manage the demands of your work } \\
\text { and family life? }\end{array}$ & .790 \\
\hline WFC: Your job reduces the effort you can give to activities at home. & .833 \\
\hline WFC: Job worries or problems distract you when you are at home. & .759 \\
\hline Marital Satisfaction & $\begin{array}{l}\text { Factor } \\
\text { Loading }\end{array}$ \\
\hline MARSAT: The physical intimacy you experience & .730 \\
\hline MARSAT: The love you experience & .884 \\
\hline MARSAT: How conflicts are resolved & .835 \\
\hline MARSAT: The amount of relationship equality you experience & .836 \\
\hline MARSAT: The amount of time you have together & .563 \\
\hline MARSAT: The quality of your communication & .872 \\
\hline MARSAT: Your overall relationship with your partner & .915 \\
\hline
\end{tabular}

\section{Constructive Communication}

\begin{tabular}{|l|l|}
\hline Self-Soothing & $\begin{array}{l}\text { Factor } \\
\text { Loading }\end{array}$ \\
\hline $\begin{array}{l}\text { SOOTHE: I've found that during an intense argument it is better to take a } \\
\text { break, calm down, then return to discuss it later }\end{array}$ & .708 \\
\hline $\begin{array}{l}\text { SOOTHE: When I am in an argument, I recognize when I am overwhelmed } \\
\text { and then make a deliberate effort to calm myself down }\end{array}$ & .815 \\
\hline $\begin{array}{l}\text { SOOTHE: While in an argument, I recognize when my partner is } \\
\text { overwhelmed and then make a deliberate effort to calm him }\end{array}$ & .749 \\
\hline
\end{tabular}

\begin{tabular}{|l|l|}
\hline Clear Sending & $\begin{array}{l}\text { Factor } \\
\text { Loading }\end{array}$ \\
\hline CLR: I discuss my personal problems with my partner & .863 \\
\hline CLR: I sit down with my partner and just talk things over & .886 \\
\hline $\begin{array}{l}\text { CLR: I talk over pleasant things that happen during the day when I am with } \\
\text { my partner }\end{array}$ & .742 \\
\hline CLR: When I talk to my partner I can say what I want in a clear manner & .804 \\
\hline
\end{tabular}

\begin{tabular}{|l|l|}
\hline Empathy & $\begin{array}{l}\text { Factor } \\
\text { Loading }\end{array}$ \\
\hline EMP: I am able to listen to my partner in an understanding way & .865 \\
\hline EMP: I understand my partners feelings & .845 \\
\hline EMP: In most matters, I understand what my partner is trying to say & .877 \\
\hline
\end{tabular}


Table 1. Factor Loadings continued

\section{Destructive Communication}

\begin{tabular}{|l|l|}
\hline Criticism & $\begin{array}{l}\text { Factor } \\
\text { Loading }\end{array}$ \\
\hline $\begin{array}{l}\text { CRIT: I don't censor my complaints at all I really let my partner have it full } \\
\text { force }\end{array}$ & .856 \\
\hline CRIT: I use a tactless choice of words when I complain & .783 \\
\hline CRIT: There's no stopping me once I get started complaining & .853 \\
\hline Contempt & $\begin{array}{l}\text { Factor } \\
\text { Loading }\end{array}$ \\
\hline $\begin{array}{l}\text { CONTEMPT: I have no respect for my partner when we are discussing an } \\
\text { issue }\end{array}$ & .869 \\
\hline $\begin{array}{l}\text { CONTEMPT: When I get upset I can see glaring faults in my partners } \\
\text { personality }\end{array}$ & .869 \\
\hline
\end{tabular}

\begin{tabular}{|l|l|}
\hline Stonewalling & $\begin{array}{l}\text { Factor } \\
\text { Loading }\end{array}$ \\
\hline $\begin{array}{l}\text { STONE: I don't feel like I have the energy to keep fighting for this } \\
\text { relationship }\end{array}$ & .886 \\
\hline STONE: I don't want to respond at all to my partner when we argue & .792 \\
\hline STONE: I have been withdrawing more and more from the relationship & .900 \\
\hline
\end{tabular}

\begin{tabular}{|l|l|}
\hline Defensiveness & $\begin{array}{l}\text { Factor } \\
\text { Loading }\end{array}$ \\
\hline DEFENSE: I feel unfairly attacked when my partner is being negative & .906 \\
\hline $\begin{array}{l}\text { DEFENSE: When my partner complains, I feel that I have to ward off these } \\
\text { attacks }\end{array}$ & .906 \\
\hline
\end{tabular}

\begin{tabular}{|l|l|}
\hline Flooding & $\begin{array}{l}\text { Factor } \\
\text { Loading }\end{array}$ \\
\hline $\begin{array}{l}\text { FLOOD: I feel physically tired or drained after I have an argument with my } \\
\text { partner }\end{array}$ & .815 \\
\hline $\begin{array}{l}\text { FLOOD: Whenever I have a conflict with my partner, I feel physically tense } \\
\text { and anxious, and I don't think clearly }\end{array}$ & .893 \\
\hline FLOOD: Whenever we have a conflict, the feelings I have are overwhelming & .902 \\
\hline
\end{tabular}


Constructive communication. Constructive communication was composed of the constructs of self-soothing, clear sending and empathy. Self-soothing measures the ability to calm oneself during an argument with items such "I've found that during an intense argument it is better to take a break, calm down, then return to discuss it later”. All factor loadings were above 0.708 . The construct of empathy measures the demonstration of empathic communication such as “I understand my partner’s feelings.” All factor loadings were above 0.845.Clear sending measures the ability to clearly express oneself such as "When I talk to my partner I can say what I want in a clear manner” (see Busby, Ivey, Harris, \& Ates, 2007). All factor loadings were above 0.742 . Constructive communication was created as a second order latent variable of the three constructs with a total of ten observed variables.

Destructive communication. Destructive communication was composed of five different constructs. The first was criticism, composed of three items measuring the degree of contempt in communications such as "I don't censor my complaints at all. I really let my partner have it full force”. All factor loadings were above 0.783 . The second construct was contempt, composed of two observed variables measuring levels of contempt in conflicts such as "I have no respect for my partner when we are discussing an issue”. Both factor loadings were 0.869.The third construct was stonewalling, three items such as "When we get in an argument I find I want to ignore my partner.” Factor loadings of all items were above 0.792 . The fourth was defensiveness, two observed variables measuring the amount of defensiveness in communication such as "I feel unfairly attacked when my partner is being negative”. Factor loadings both items were 0.906 . Finally, flooding was a latent variable composed of three observed variables such as “Whenever I have a conflict with my partner, I feel physically tense and anxious, and I don’t 
think clearly”. All factor loadings were above 0.815. All five constructs created a second order latent variable of destructive criticism totaling thirteen observed variables.

Each of these items, criticism, contempt, stonewalling, defensiveness and flooding, measure factors that Gottman (1994) found to be predictive of relationship distress or separation (see also Gardner, Busby \& Brimhall, 2007) and therefore are grouped and labeled as destructive communication.

Control variables. Gender, level of education and length of marriage were used as control variables. Gender is a logical mediator because men and women communicate in different ways, experience different kinds of work-family conflict and report different levels of marital satisfaction. Level of education has an impact on job level. Job level in turn impacts the experience of work-family conflict. Level of education also is linked with marital satisfaction and increased communication skills. Therefore level of education was used as a control. Newlyweds communicate in qualitatively different ways than do marriages at a later life stage. Marital satisfaction varies as well throughout the life course and work-family conflict is experienced in different ways in different life stages as well. Therefore length of marriage was included as a control variable in this model. These variables have been used as controls in other studies regarding work-family conflict, marital satisfaction and communication (see Byron, 2005).

\section{Analysis and Results}

Means, standard deviations and correlations for all study variables are shown in Table 2. 
Table 2. Means, Standard Deviation and Correlations

\begin{tabular}{|c|c|c|c|c|c|c|c|c|}
\hline Variable & Overall M (SD) & 1 & 2 & 3 & 4 & 5 & 6 & 7 \\
\hline 1. Gender (1= Male, 2=Female) & $1.45(.50)$ & 1 & & & & & & \\
\hline 2. Education (1 to 9) & $7.01(1.91)$ & $.070 *$ & 1 & & & & & \\
\hline 3. Length of Marriage (years) & $5.35(2.40)$ & $-.137 * *$ & .053 & 1 & & & & \\
\hline $\begin{array}{l}\text { 4. Work-Family Conflict } \\
\qquad(\alpha=.71 \text {, range } 1 \text { to } 5)\end{array}$ & $3.00(.76)$ & .038 & $.064^{*}$ & $.135^{* *}$ & 1 & & & \\
\hline $\begin{array}{l}\text { 5. Constructive Communication } \\
\qquad(\alpha=.84,1.8 \text { to } 5)\end{array}$ & $3.57(.58)$ & .024 & .050 & $-.181^{* *}$ & $-.240^{* *}$ & 1 & & \\
\hline $\begin{array}{l}\text { 6. Destructive Communication } \\
\qquad(\alpha=.90,1 \text { to } 4.35)\end{array}$ & $2.58(.73)$ & $.085 * *$ & -.015 & $.119 * *$ & $.321^{* *}$ & $-.631^{* *}$ & 1 & \\
\hline $\begin{array}{l}\text { 7. Marital Satisfaction } \\
\qquad(\alpha=.91,1 \text { to } 5)\end{array}$ & $3.38(.95)$ & -.048 & -.032 & $-.251^{* *}$ & $-.306^{* *}$ & $.687 * *$ & $-.706^{* *}$ & 1 \\
\hline
\end{tabular}




\section{Work-Family Conflict and Marital Satisfaction}

Using Analysis of Moment Structures (AMOS 20) software for structural equation modeling $(\mathrm{SEM})$, the structural model for hypothesis one fit the data: $\chi^{2}(55)=293.479, \mathrm{p}<.01$; Tucker-Lewis index $(\mathrm{TLI})=.940 ;$ comparative fit index $(\mathrm{CFI})=.964$; the root mean square error of approximation $($ RMSEA) $=.062$ (Arbuckle, 2011).

Hypothesis 1 was fully supported (see Figure 2). Work-family conflict was negatively and significantly related to marital satisfaction $(\beta=-.029, \mathrm{p}<.01)$ controlling for gender, length of marriage and education.

\section{Communication as a Mediator}

A structural equation model tested hypothesis two and three, if constructive and destructive communication mediated the relationship between work-family conflict and marital satisfaction. This model also fit the data: $\chi^{2}(560)=2627.823, \mathrm{p}<.01$; Tucker-Lewis index (TLI) $=.889$; comparative fit index $(\mathrm{CFI})=.906$; the root mean square error of approximation $($ RMSEA $)=.057($ Arbuckle, 2011)

According to the Baron and Kenny (1986) approach to determine mediation, the pathway between the independent variable and the dependent variable is labeled as pathway A. Pathway $\mathrm{B}$ is from the independent variable to the mediating variable and pathway $\mathrm{C}$ from the mediating variable to the dependent variable (see Figure 3). 
Figure 2. Hypothesis One Results

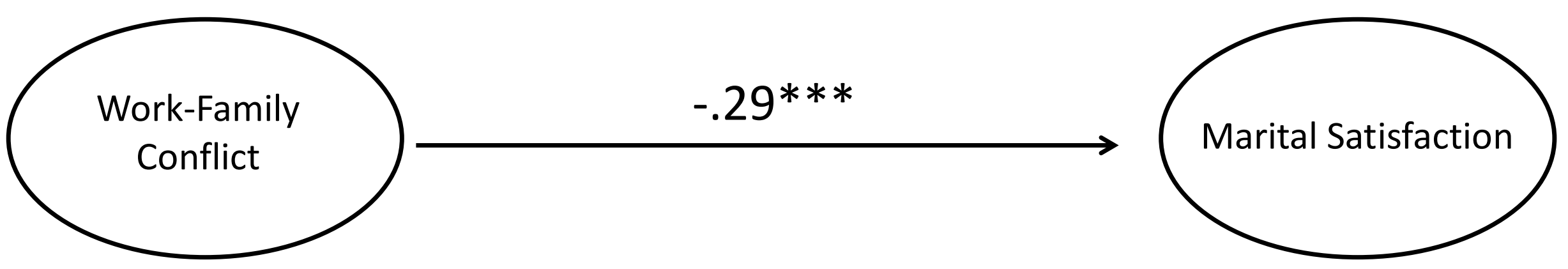

Notes: Work-family conflict was negatively and significantly associated with marital satisfaction when controlling for gender, length of marriage and level of education. Model fit statistics: $\chi^{2}(55)=293.479, \mathrm{p}<.01$; TLI $=.940 ; \mathrm{CFI}=.964 ; \mathrm{RMSEA}=.062$.

Standardized beta weight 
Figure 3. Baron and Kenny Hypothesis

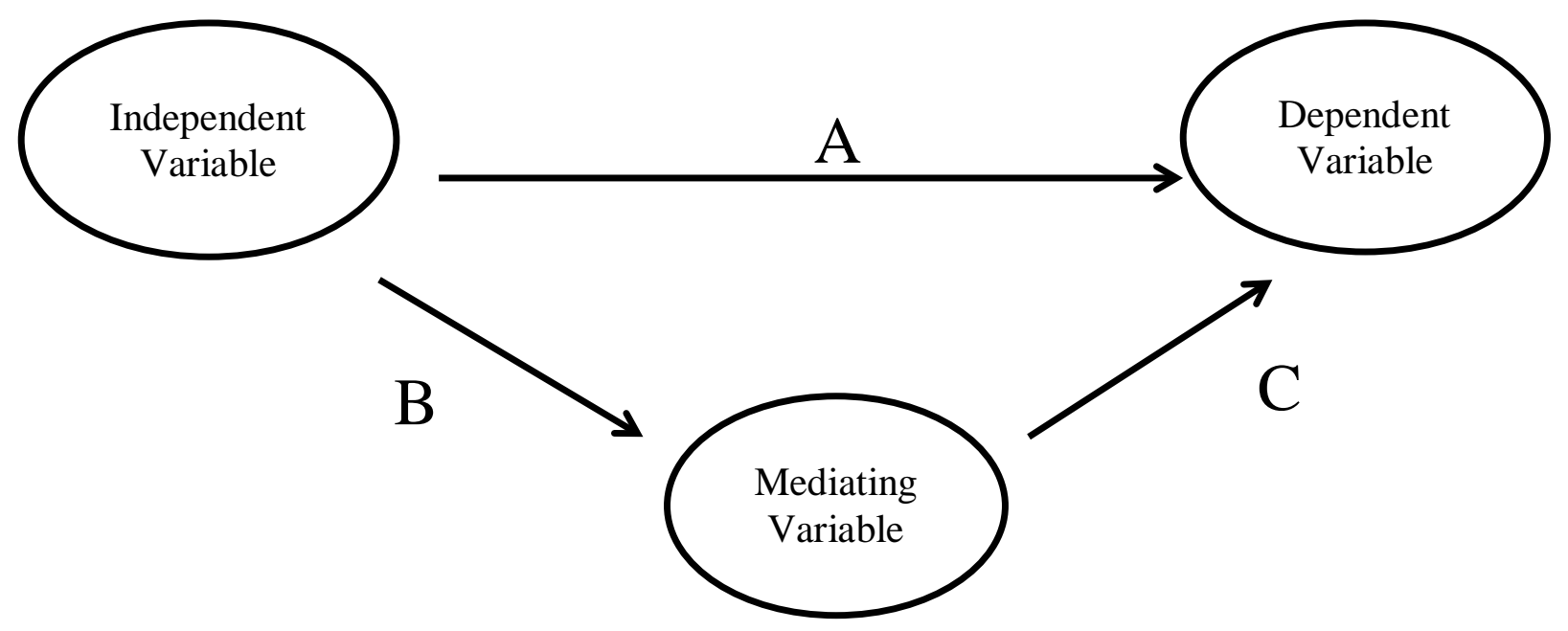

Hypothesis two was fully supported (see Figure 4). Destructive communication fully mediated the negative relationship between work-family conflict and marital satisfaction. Workfamily conflict was significantly and positively associated with destructive communication ( $\beta$ $=.340, p<.01$ ) and destructive communication was significantly and negatively associated with marital satisfaction $(\beta=-.624, p<.01)$. In this model, work-family conflict was not significantly associated with marital satisfaction ( $\beta=.008, p=$ ns). Sobel's (1982) test confirms the significance of the indirect effects of these mediators. The Sobel test statistic for this model produced - 7.053, $p<.01$

Hypothesis three was also fully supported (see Figure 4). Constructive communication fully mediated the negative relationship between work-family conflict and marital satisfaction. Work-family conflict was significantly and negatively related to constructive communication ( $\beta$ $=-.299, p<.01$ ) and constructive communication was significantly and positively related to marital satisfaction ( $\beta=.301, p<.01$ ). Again, the relationship between work-family conflict and marital satisfaction was not significant $(\beta=.008, p=n s)$. Sobel's (1982) test confirms the significance of this indirect effect with a test statistic of $-4.965, p<.01$. 
Figure 4. Hypotheses Two and Three Results

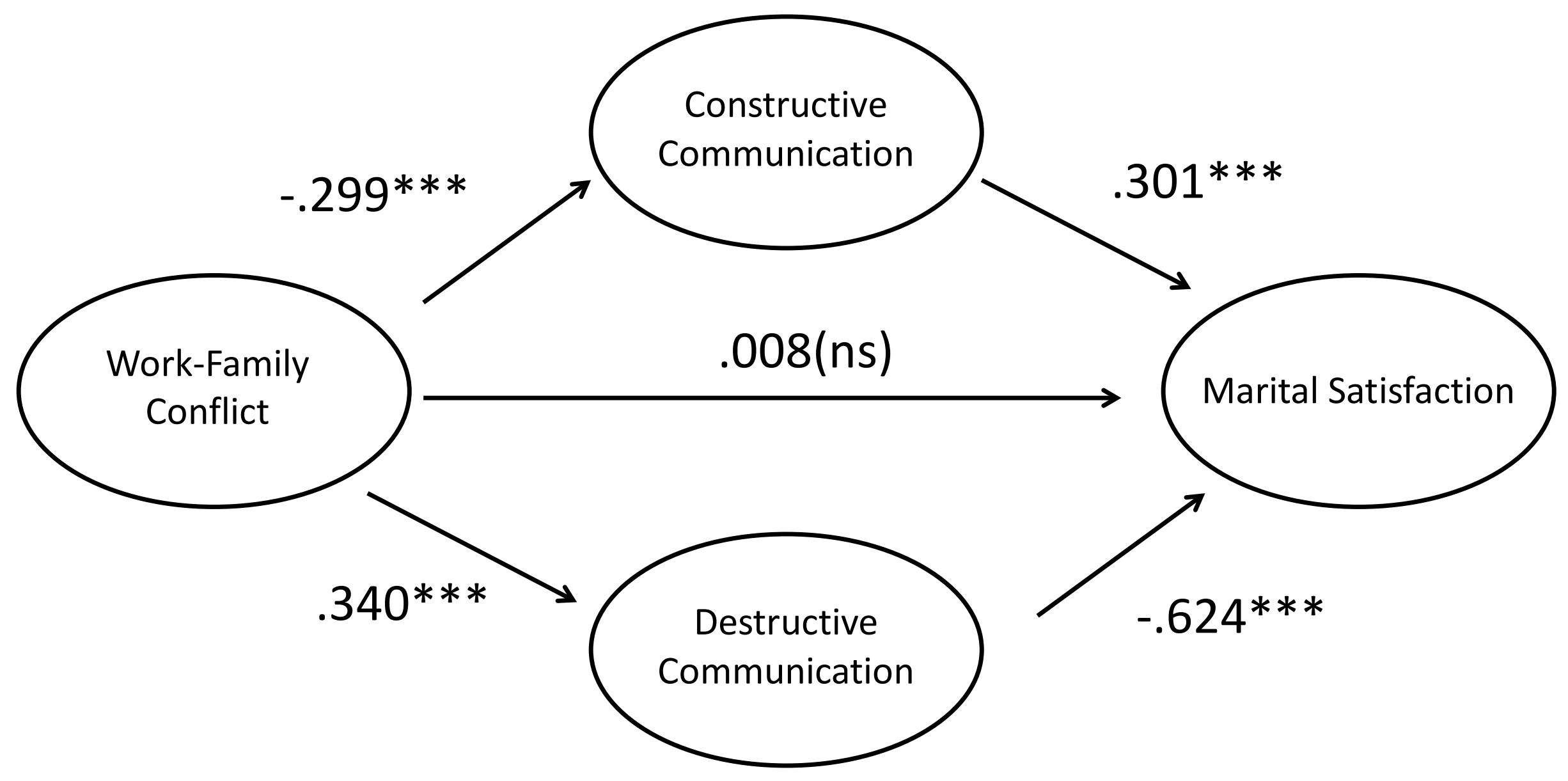

Notes: Constructive communication and destructive communication each fully mediated the relationship between work-family conflict and marital satisfaction while controlling for gender, length of marriage and level of education. Standardized beta weights Model fit statistics: $\chi^{2}(560)=2627.823, \mathrm{p}<.01 ; \mathrm{TLI}=.889 ; \mathrm{CFI}=.906 ; \mathrm{RMSEA}=.057$ 
Constructive and destructive communication fully mediated the relationship of workfamily conflict and marital satisfaction. The relationship between work-family conflict and marital satisfaction is significant without mediators but the model with mediators shows the link between work-family conflict and marital satisfaction as no longer significant. The change in the pathway from significant to non-significant demonstrates that constructive and destructive communication fully mediated the relationship between work-family conflict and marital satisfaction (see Baron \& Kenny, 1986; Preacher \& Hayes, 2004). Table 3 emphasizes the indirect effect of work-family conflict on marital satisfaction.

The results of the control variables for the full model are as follows: Controlling for marital satisfaction, marriage length $(\beta=-.077, \mathrm{p}<.01)$, education level $(\beta=-.066, \mathrm{p}<.01)$ and gender $(\beta=-.028, \mathrm{p}=\mathrm{ns})$. Controlling for constructive communication, results showed marriage length $(\beta=-.163, \mathrm{p}<.01)$, education level $(\beta=.088, \mathrm{p}=\mathrm{ns})$ and gender $(\beta=.047$, $\mathrm{p}=\mathrm{ns})$.Controlling for destructive communication, marriage length $(\beta=.167, \mathrm{p}<.01)$, education level $(\beta=-.055, \mathrm{p}=\mathrm{ns})$, and $\operatorname{gender}(\beta=.086, \mathrm{p}=\mathrm{ns})$. 
Table 3. Decomposition of Standardized Effects from SEM of Work-family Conflict Predicting Marital Satisfaction, with Constructive Communication and Destructive Communication as Mediating Variables

$\begin{array}{llc}\text { Direct } & \text { Indirect } & \text { Total } \\ \text { Effects } & \text { Effects } & \text { Effects }\end{array}$

Effects on Effective Communication

Work-family Conflict

Effects on Destructive Communication

Work-family Conflict

Effects on Marital Satisfaction

Effective Communication

Destructive Communication

Work-family Conflict

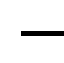

\begin{tabular}{|c|c|c|}
\hline - 0.302 & - & -0.302 \\
\hline 0.345 & - & 0.345 \\
\hline 0.305 & - & 0.305 \\
\hline - 0.617 & - & -0.617 \\
\hline 0.007 & -0.305 & -0.298 \\
\hline
\end{tabular}

Note: Standard errors for indirect and total effects are not calculated. See Figure 4 for significance tests of direct effects. 


\section{Discussion}

Given that work-family conflict is a salient issue for couples (Risch et al., 2003), marriage and high marital satisfaction are beneficial (Waite \& Gallagher, 2000), and low marital satisfaction is harmful (Hawkins \& Booth, 2005), this study makes a valuable contribution by examining a mediator of the relationship between work-family conflict and marital satisfaction. Considering the established association between high work-family conflict and lower marital satisfaction (see Allen et al., 2000; Ford et al., 2007; Michel et al., 2009; Hill et al., 2011), it is useful to explore what mediates this relationship for the purpose of facilitating marital satisfaction.

Constructive communication is one of those mediating variables according to the results of the present study. Holman (2001) found that the quality of couple communication is one of the best predictors of marital satisfaction and the present study also suggests that high quality couple communication can also be a buffer against factors that would lead to lower marital satisfaction. This study’s findings are consistent with previous research supporting links between constructive communication and marital quality (e.g. Perrone \& Worthington, 2001; Feeney, 1994) , as well as the links between constructive communication and work-family conflict (e.g. Minnotte et al., 2007; Doumas et al., 2003). The current study is unique in that it specifically offers support for constructive communication as a mediator between the variables of work-family conflict and marital satisfaction .

Destructive communication is another mediating variable to the relationship between work-family conflict and marital satisfaction. Gottman (1994) proclaims that criticism, contempt, defensiveness, and stonewalling send a marriage careening toward divorce. This study demonstrates that such destructive communication can also exacerbate the effects of work-family 
conflict. This study ties together and amplifies previous findings linking destructive communication with lower marital quality (e.g. Siffert \& Schwarz, 2011; Jackson, 2009) as well as previous findings linking work-family conflict and destructive communication (Green et al., 2011; Schulz et al., 2004).

In the present study, constructive communication and destructive communication each fully mediated the relationship between work-family conflict and marital satisfaction. In accordance with family stress theory, constructive communication is a resource that spouses may use to cope with the stressors of life and be able to adapt. Conversely, destructive communication adds to the stress pileup with deleterious results.

\section{Implications}

The findings of this study have implications for employers, clinicians, family life educators and individuals experiencing conflict between paid work and family life. Employers make many efforts to reduce work-family conflict, as evidenced by their offering flexibility or child-care assistance. Such efforts are useful. However, since the mastery of communication skills seems to ameliorate the effects of work-family conflict on marital satisfaction, an employee’s marital communication skills is a potentially rich point of intervention. Managers could offer marital communication skills training in their workplace, allowing an opportunity for their employees to increase their marital satisfaction even though work demands may still remain high. A side benefit might be that these same communication skills may help make the employees more effective on the job as well.

In a clinical setting, conflicts between work and family are rated as a top problematic issue (Risch et al., 2003). Therefore, clinicians would do well to note that teaching constructive communication skills and eliminating of destructive communication skills could change the 
impact of the work-family conflict on their clients' marriages. Furthermore, destructive communication mediated the relationship between work-family conflict and marital satisfaction more powerfully than constructive communication. It is often those couples that have high levels of destructive communication that present for therapy. Couples in distress that can lessen the levels of criticism, defensiveness, contempt, stonewalling and flooding will likely handle the stresses of life better. The cessation of negativity alone, however, is insufficient; there must also be a balance of positivity. Gottman (1994) emphasises that this ratio needs to be at least five positive interactions for every one negative interaction. The Gottman Method for couple’s therapy is an effective intervention to increase positive interactions and reduce negative interactions in distressed couples (Gottman, 1999). Employers can link employees to the necessary services through employee assistance programs. Research suggests marriage and family therapists have much to offer to employee assistance programs (Shumway, et al., 2004) and the findings of this study emphasize the need to improve marital communication.

Family life educators also could focus their efforts on the coaching of communication skills among couples that experience high levels of work-family conflict. Many couples that experience work-family conflict are not to a level of distress that they present for therapy. Rather, they may seek relationship enhancement from a family life educator. Many relationship enhancement programs focus on communications skills such as PREP (Stanley, Blumberg \& Markman, 1999). Family life educators would also do well to note the specific focus on eliminating the destructive communication and increasing constructive communication. Changing a couple's way of communication, may change the manner in which stresses of life, such as conflict between work and family life, affect that couple's level of marital satisfaction. 
Finally, individuals can recognize the pattern seen in this model. Stressful events and circumstances can attack the relationship between husband and wife. In order to avoid such an effect, decrease negativity and increase positivity in processes of communication. These skills can be learned with effort. Relationship maintanance, putting effort into improving one’s relationship, in and of itself is associated with greater marital satisfaction (Weigel \& BallardReisch, 2008). Furthermore, the findings of this study advocate that improving communication skills can be beneficial to ameliorate the negative effects of work-family conflict. Communication skills can create a shield such that the stresses of life are not an attack to a marriage, but instead such stresses can fuel a husband and wife's abilty to be a team, and together tackle the challenges of life.

\section{Strengths and Limitations}

This study has many strengths. This sample of this study was relatively large $(N=1,139)$. With the high levels of education, low levels of income and high levels of work hours, this sample reflects the common person. This aspect of the sample encourages the findings and impliations to be generalized to other married employees.

Another strength lies in the distinction between constructive and destructive communication. Communication was not lumped into one composite measure, rather it was conceptualized as two distinct variables. By examining constructive and destructive communication separately, the relative effects of each are more apparent. Destructive communication has a stronger mediating effect than constructive communication.

This study is not without limitiations. The sample is not considered to be representative of the United States population, and therefore results may not be confidently generalized to the population at large. Particularly, 29\% of the sample declared their religion as LDS, which is 
disproportionate to the U.S. population. However, there is some evidence to suggest that LDS populations do not differ significantly from the non-LDS population in terms of family and work (Goodman \& Heaton, 1986).

Also, only those working full-time (35 hours a week or more) were selected to be included in the sample. It was left unexplored if a distinct effect exists for part-time workers. This study also did not distinguish between dual-earner and single-earner families, and such structural differences can affect the type of work-family conflict experienced (Galambos \& Walters, 1992).

In the current sample, the data were not paired, however no controls were made to ensure both married partners were not included in the sample. Therefore it may be possible that two individuals within the dataset responded regarding their marriage to each other, which may confound the data. However, this cannot be determined and is therefore a limitation of the present study. Future research may consider examining cross-over effects with dyadic data.

Finally, this study examined work-family conflict as the independent variable and marital satisfaction. It may be that work-family conflict is not independent of marital satisfaction, but that these two variables may have a reciprical relationship.

\section{Conclusion}

Constructive and destructive communication each fully mediate the relationship between work-family conflict and marital satisfaction. Communicating constructively as well as avoiding patterns of destructive communication are skills that can be taught. The husband who struggles with business trips leading to arguments with his wife can learn to lessen his defensiveness, learn to self-soothe in the heat of an argument and to refrain from withdrawing from the relationship. At the same time he can learn to speak with greater clarity and listen with greater empathy. As 
well, the wife who juggles her rigid work schedule with her children's soccer games can learn to eliminate criticism and contemptous remarks from her communication with her husband regarding the pandemonium of their daily life. She can learn to express with clarity her appreciation and display greater understanding for her husband's situation as well. Learning such skills of constructive communication and avoiding destructive communication can lessen the degree that the conflict between work and family impacts the satisfaction between husband and wife. 


\section{References}

Acitelli, L. K., \& Antounucci, T. C. (1994). Gender differences in the link between marital support and satisfaction in older couples. Journal of Personality and Social Psychology, 67, 688-698.

Allen, T. D., Herst, D. E. L., Bruck, C. S., \& Sutton, M. (2000). Consequences associated with work-to-family conflict: A review and agenda for future research. Journal of Occupational Health Psychology, 5, 278-308. doi: 10.1037//1076-899B.5.2.278

Arbuckle, J. L. (2011). IBM SPSS Amos 20 User's Guide. IBM Corporation, Armonk, NY.

Bakker, A. B., Demerouti, E., \& Burke, R. (2009). Workaholism and relationship quality: A spillover-crossover perspective. Journal of Occupational Health Psychology, 14, 23-33. doi: $10.1037 / \mathrm{a} 0013290$.

Barling, J., \& Macewen, K. E. (1992). Linking work experiences to facets of marital functioning. Journal of Organizational Behavior, 13, 573-583.

Baron, R. M., \& Kenny, D. A. (1986). The moderator-mediator variable distinction in social psychological research: Conceptual, strategic, and statistical considerations. Journal of Personality and Social Psychology, 51, 1173-1182.

Birditt, K. S., Brown, E., Orbuch, T. L., \& McIlvane, J. M. (2010). Marital conflict behaviors and implications for divorce over 16 years. Journal of Marriage and Family, 72, 11881204. doi:10.1111/j.1741-3737.2010.00758.x

Brock, R. L., \& Lawrence, E. (2008). A longitudinal investigation of stress spillover in marriage: Does spousal support adequacy buffer the effects? Journal of Family Psychology, 22, 1120. doi: 10.1037/0893-3200.22.1.11 
Bui, K-V. T., Peplau, L. A., \& Hill, C. T. (1996). Testing the Rusbult model of relationship commitment and stability in a 15-year study of heterosexual couples. Personality and Social Psychology Bulletin, 22, 1244-1257. doi: 10.1177/01461672962212005

Busby, D. M., Holman, T. B., \& Taniguchi, N. (2001). RELATE: Relationship evaluation of the individual, family, cultural, and couple contexts. Family Relations, 50, 308-316.

Busby, D. M., Ivey, D. C., Harris, S. M., \& Ates, C. (2007). Self-directed, therapist-directed, and assessment-based interventions for premarital couples. Family Relations, 56, 279_ 290.

Byron, K. (2005). A meta-analytic review of work-family conflict and its antecedents. Journal of Vocational Behavior, 67, 169-198. doi:10.1016/j.jvb.2004.08.009

Day, A. L., \& Chamberlain, T. C. (2006). Committing to your work, spouse, and children: Implications for work-family conflict. Journal of Vocational Behavior, 68, 116-130. doi:10.1016/j.jvb.2005.01.001

Dehle, C., Larsen, D., \& Landers, J. E. (2001). Social support in marriage. American Journal of Family Therapy, 29, 307-324.

Dennis, S. A. (1996). The influence of workplace stressors, resources, and perceptions on workto-family spillover: An application of the double ABCX model (Doctoral Dissertation: Utah State University, 1996). Dissertation Abstracts International, 57(3-A), 1335.

Doumas, D. M., Margolin, G., \& John, R. S. (2003). The relationship between daily marital interaction, work, and health-promoting behaviors in dual-earner couples. Journal of Family Issues, 24, 3-20. doi: 10.1177/0192513X02238518 
Eby, L. T., Casper, W. J., Lockwood, A., Bordeaux, C., \& Brinely, A. (2005). Work and family research in IO/OB: Content analysis and review of the literature (1980-2002). Journal of Vocational Behavior, 66, 124-197. doi:10.1016/j.jvb.2003.11.003

Feeney, J. A. (1994). Attachment style, communication patterns, and satisfaction across the life cycle of marriage. Personal Relationships, 1, 333-348.

Ford, M. T., Heinen, B.A., \& Langkamer, K. L. (2007). Work and family satisfaction and conflict: A meta-analysis of cross-domain relations. Journal of Applied Psychology, 92, 57-80. doi: 10.1037/0021-9010.92.1.57

Galambos, N. L., \& Walters, B. J. (1992). Work hours, schedule inflexibility, and stress in dualearner spouses. Canadian Journal of Behavioural Science, 24, 290-302.

Gardner, B. C., Busby, D. M., \& Brimhall, A. S. (2007). Putting emotional reactivity in its place? Exploring family-of-origin influences on emotional reactivity, conflict, and satisfaction in premarital couples. Contemporary Family Therapy, 27, 113-127. doi 10.1007/s10591007-9039-x

Goodman, K., \& Heaton, T. B. (1986). LDS Church members in the U.S. and Canada: A demographic profile. AMCAP Journal, 12(1), 88-107.

Gottman, J. M. (1994). What predicts divorce? The relationship between marital processes and marital outcomes. Hillsdale, NJ: Laurence Erlbaum Associates, Publishers.

Gottman, J. M. (1999). The marriage clinic: A scientifically based marital therapy. New York, NY: W.W. Norton \& Company Inc.

Gottman, J. M., \& Levenson, R. W. (1992). Marital processes predictive of later dissolution: Behavior, physiology, and health. Journal of Personality and Social Psychology, 63, 221-233. 
Green, S. G., Schaefer, R. A. B., MacDermid, S. M., \& Weiss, H. M. (2011). Partner reactions to work-to-family conflict: Cognitive appraisal and indirect crossover in couples. Journal of Management, 37, 744-769. doi: 10.1177/0149206309349307

Greenhaus, J. H., \& Beutell, N. J. (1985). Sources of conflict between work and family roles. Academy of Management Review, 10, 76-88.

Hawkins, D. H., \& Booth, A. (2005). Unhappily ever after: Effects of long-term, low-quality marriages on well-being. Social Forces, 84, 451-471.

Henderson-King, D. H., \& Veroff, J. (1994). Sexual satisfaction and marital well-being in the first years of marriage. Journal of Social and Personal Relationships, 11, 509-534.

Hill, E. J. (2005). Work-family facilitation and conflict, working fathers and mothers, workfamily stressors and support. Journal of Family Issues, 26, 793-819.

doi:10.1177/0192513X05277542

Hill, E. J., Fellows, K. J., Chiu, H-.Y., \& Hawkins, A. J. (2011, August). Work-family conflict and couple relationship quality: A meta-analytic study. Poster session presented the meeting of the American Psychological Association, Washington, D.C.

Hill, R. (1958). Social stresses on the family: Generic features of families under stress. Social Casework, 39, 139-150.

Holman, T. B. (Ed.). (2001). Premarital prediction of marital quality or breakup: Research, theory, and practice. New York: Kluwer Academic/Plenum.

Holman, T. B., Busby, D. M., Doxey, C., Klein, D. M., \& Loyer-Carlson, V. (1997). The RELATionship Evaluation. Provo, UT: Center for Family Studies. 
Ilies, R. Wilson, K. S., \& Wagner, D. T. (2009). The spillover of daily job satisfaction onto employees' family lives: The facilitating role of work-family integration. Academy of Management Journal, 52, 87-102.

Jackson, J. B. (2009). Premarital couple predictors of marital relationship quality and stability: A meta-analytic study. (Doctoral dissertation). Available from Proquest Dissertations and Theses database (UMI No. 3380523).

Jacob, J. I., Allen, S., Hill, E. J., Mead N. L., \& Ferris, M. (2008). Work interference with dinnertime as a mediator and moderator between work hours and work and family outcomes. Family and Consumer Sciences Research Journal, 36, 310-327. doi: $10.1177 / 1077727 X 08316025$

Johnson, M. D., Cohan, C. L., Davila, J., Lawrence, E., Rogge, R. B., Karney, B. R., Sullivan, K. T., \& Bradbury, T. N. (2005). Problem-solving skills and affective expressions as predictors of change in marital satisfaction. Journal of Counseling and Clinical Psychology, 73, 15-27. doi: 10.1037/0022-006X.73.1.15

Jones, B. L., Scoville, D. P., Hill, E. J., Childs, G., Leishman, J. M., \& Nally, K. S. (2008). Perceived versus used workplace flexibility in Singapore: Predicting work-family fit. Journal of Family Psychology, 22, 774-783. doi: 10.1037/a0013181

Judge, T. A., Ilies, R., \& Scott, B. A. (2006). Work-family conflict and emotions: Effects at work and at home. Personnel Psychology, 59, 779-814.

Kinnunen, U., \& Mauno, S. (1999). The effects of job stressors on marital satisfaction in Finnish dual-earner couples. Journal of Organizational Behavior, 20, 879-895. 
Kossek, E. E., \& Ozeki, C. (1998). Work-family conflict, policies, and the job-life satisfaction relationship: A review and directions for organizational behavior-human resources research. Journal of Applied Psychology, 83, 139-149.

Larson, J. H., \& Holman, T. B. (1994). Premarital predictors of marital quality and stability. Family Relations, 43, 228-237.

Larson, J. H., Anderson, S. M., Holman, T. B., \& Niemann, B. K. (1998). A longitudinal study of the effects of premarital communication, relationship stability, and self-esteem on sexual satisfaction in the first year of marriage. Journal of Sex \& Marital Therapy, 24(3), 193- 206. doi: 10.1080/00926239808404933

Lewis, R. A., \& Spanier, G. B. (1979). Theorizing about the quality and stability of marriage. In W. R. Burr, R. Hill, F. I . Nye, \& I. L. Reiss (Eds.), Contemporary theories about the family (Vol 1, pp. 268-294). New York, NY: Free Press.

Macewen, K. E., \& Barling, J. (1988). Interrole conflict, family support and marital adjustment of employed mothers: A short term, longitudinal study. Journal of Organizational Behavior, 9, 241-250.

Matthews, L. S., Conger, R. D., \& Wickrama, K. A. S. (1996). Work-family conflict and marital quality: Mediating processes. Social Psychology Quarterly, 59, 62-79.

Matthews, R. A., Del Priore, R. E., Acitelli, L. K., \& Barnes-Farrell, J. L. (2006). Work-torelationship conflict: Crossover effects in dual-earner couples. Journal of Occupational Health Psychology, 11, 228 -240. DOI: 10.1037/1076-8998.11.3.228

McCubbin, H., \& Patterson, J. (1983). The family stress process: The double ABCX model of family adjustment and adaptation. Marriage and Family Review, 6, 7-37. 
Michel, J. S., Mitchelson, J. K., Kotrba, L. M., LeBreton, J. L, \& Baltes, B. B. (2009). A comparative test of work-family conflict models and critical examination of work-family linkages. Journal of Vocational Behavior 74, 199-218. doi:10.1016/j.jvb.2008.12.005

Minnotte, K. L., Stevens, D. P., Minnotte, M. C., \& Kiger, G. (2007). Emotion-work performance among dual-earner couples: Testing four theoretical perspectives. Journal of Family Issues, 28, 773- 793. doi: 10.1177/0192513X07299676

Pasch, L. A., \& Bradbury, T. N. (1998). Social support, conflict, and the development of marital dysfunction. Journal of Consulting and Clinical Psychology, 66, 219-230.

Perrone, K. M., \& Worthington, E. L. (2001). Factoring influencing ratings of marital quality by individuals within dual-career marriages: A conceptual model. Journal of Counseling Psychology, 48, 3-9. doi: 10.1037W0022-0167.48.1.3

Preacher, K. J., \& Hayes, A. F. (2004). SPSS and SAS procedures for estimating indirect effects in simple mediation models. Behavior Research Methods, Instruments, \& Computers, 36, 717-731.

Repetti. R. L. (1989). Effects of daily workload on subsequent behavior during marital interaction: The roles of social withdrawal and spouse support. Journal of Personality and Social Psychology, 57, 651-659.

Risch, G. S., Riley, L. A., \& Lawler, M. G. (2003). Problematic issues in the early years of marriage: Content for premarital education. Journal of Psychology and Theology, 31, 253-269.

Sandberg, J. G., Yorgason, J. B., Miller, R. B., \& Hill, E. J. (2012). Family-to-work spillover in Singapore: Marital distress, physical and mental health, and work satisfaction. Family Relations, 61, 1-15. doi:10.1111/j.1741-3729.2011.00682.x 
Schulz, M. S., Cowan, P. A., Cowan, C. P., \& Brennan, R. T. (2004). Coming home upset: Gender, marital satisfaction, and the daily spillover of workday experience into couple interactions. Journal of Family Psychology, 18, 250-263. doi: 10.1037/08933200.18.1.250

Shumway, S., Wampler, R., Dersch, C.,\& Arredondo, R. (2004).A place for marriage and family services in employee assistance programs (EAPs):A survey of EAP client problems and needs. Journal of Marital \& Family Therapy, 30, 71-79.

Siffert, A., \& Schwarz, B. (2011). Spouses’ demand and withdrawal during marital conflict in relation to their subjective well-being. Journal of Social and Personal Relationships, 28, 262-277. doi: 10.1177/0265407510382061

Sobel, M. E. (1982). Asymptotic confidence intervals for indirect effects in structural equations models. Sociological Methodology, 13, 290-312.

Stanley, S. M., Blumberg, S. L., Markman, H. J. (1999). Helping couples fight for their marriages: The PREP approach. In R. Berger, \& M. T. Hannah (Eds), Preventive approaches in couples therapy (pp. 279-303). Philadelphia, PA, US: Brunner/Mazel.

Suchet, M., \& Barling, J. (1986). Employed mothers: Interrole conflict, spouse support and marital functioning. Journal of Occupational Behavior, 7, 167-178.

Swanson, V., \& Power, K. G. (1999). Stress, satisfaction and role conflict in dual-doctor partnerships. Community, Work \& Family, 2, 67-88.

Voydanoff, P. (2005). Social integration, work-family conflict and facilitation, and job and marital quality. Journal of Marriage and Family, 67, 666-679.

Waite, L. J., \& Gallagher, M. (2000). The case for marriage: Why married people are happier, healthier, and better off financially. New York, NY: Double Day. 
Wallerstein, J. S., Lewis, J. M., \& Blakeslee, S. (2000). The unexpected legacy of divorce: A 25 year landmark study. New York, NY: Hyperion.

Weigel, D. J., \& Ballard-Reisch, D. S. (2008). Relational maintenance, satisfaction and commitment in marriages: An actor-partner analysis. Journal of Family Communication, 8, 212-229. doi: 10.1080/15267430802182522

Wu, M., Chang, C.-C., \& Zhuang, W.-L. (2010). Relationships of work-family conflict with business and marriage outcomes in Taiwanse copreneurial women. The International Journal of Human Resource Management, 21, 742-753.

doi:10.1080/09585191003658912 